ISLAH: Journal of Islamic Literature and History

Vol. 1, No. 1, June 2020: p. 21-30. DOI: 10.18326/islah.v1i1.21-30

Website: https://e-journal.iainsalatiga.ac.id/index.php/islah

\title{
Swaraning Ngasepi Manuscript And the Makings Of Islamic Culture In the Javanese Muslim
}

\author{
Siti Mariatul Kiptiyah \\ IAIN Ponorogo \\ sitimariatulkiptiyah1@gmail.com
}

\begin{abstract}
The article concerns on Javanese Islam manuscript entitled Swaraning Ngasepi at the library of Dewantara Kirti Griya Museum, Yogyakarta. The focus of this study is to describe the physical aspect of the manuscript and to examine the content of text especially the idea about the making of Islamic culture. The data was collected through documentary research and analyzed using philology. This study shows that the text talks about how to obtain revelation through Islamic procedures. This text criticizes the practice of asceticism in solitude in the lonely places that the Javanese people used to do in the past to obtain magical guidance.
\end{abstract}

Keywords: Islam, Java, manuscript, revelation

\begin{abstract}
Abstrak
Artikel ini membahas manuskrip Islam Jawa berjudul Swaraning Ngasepi koleksi Perpustakaan Museum Dewantara Kirti Griya, Yogyakarta. Penelitian ini fokus pada deskripsi fisik naskah dan isi teksnya terutama terkait dengan gagasan pembentukan kultur islami yang terkandung di dalam teks. Data dikumpulkan dengan studi dokumentasi dan dianalisis dengan pendekatan filologi. Hasil penelitian ini menunjukkan bahwa teks itu menjelaskan tentang cara memperoleh petunjuk dari Tuhan untuk menjalani kehidupan yang harus ditempuh dengan laku islami. Dari penjelasannya, teks ini mengkritik laku bertapa dengan menyepi di tempat-tempat sunyi yang lazim dilakukan orang Jawa pada masa lalu untuk memperoleh petunjuk gaib.
\end{abstract}

Kata kunci: Islam, Jawa, manuskrip, wahyu

\section{INTRODUCTION}

The existence of Islam in Indonesia led to a significant writing tradition. There are many Islamic texts written for teaching purposes, preserving local characters and languages, and maintaining nationalism in colonial politics which is inherited as cultural memory. ${ }^{1}$ Not only in Pesantren or Islamic boarding schools, but the birth of various Islamic associations or institutions also contributed to the printing of cultural memory through texts of Islamic

\footnotetext{
${ }^{1}$ About archives in Indonesia was discussed by Umam with attention to how historical documents can be reviewed properly and contribute to the nation. See: Zacky Khairul Umam, "Islam, Arsip, Dan Arsipelago: Sebuah Refleksi Keindonesiaan,” Jurnal Sejarah 1, No. 1 (2017): 105 - 120.
} 
teachings written in local languages, such as the Muhammadiyah movement in Yogyakarta, $1912 .^{2}$

Muhammadiyah became one of the movement Muslim societies in the early 20th century who brought the tradition of writing carakan and Javanese languages into Islamic discourse. ${ }^{3}$ Muhammadiyah scholars wrote many copies of Arabic books in various fields of Islamic studies and new writings that refer to the main books were written using the Javanese language and carakan script, before then writing in Latin script while still using the local language. Their books have historically informed us how Islam at that time was taught as well as studied in Javanese society, specifically the Kauman community as the basis of the early Muhammadiyah.

Among the Islamic books proposed by Muhammadiyah scholars and important to discuss is Swaraning Ngasepi. This completes several similar works in the field of monotheism, commentary, hadith, and fiqh. ${ }^{4}$ The Swaraning Ngasepi manuscript is collected at the library of Dewantara Kirti Griya Museum, Yogyakarta. This article focuses on the making of Islamic culture in the text. It is necessary to study because it was a carakan (hanacaraka) document in the early of the 20th century written by intellectual of Muhammadiyah.

As is commonly recognized by many scholars, Muhammadiyah is puritan movement. ${ }^{5}$ Appreciation of Muhammadiyah to the Javanese script in some of their Islamic books included Swaraning Ngasepi, gives an interesting impression in this discussion. In this article, I would like to explore the Swaraning Ngasepi manuscript as one of the Islamic literature in the earlier of Muhammadiyah. As Islamic literature, Swaraning Ngasepi contains Islamic

\footnotetext{
${ }^{2}$ Some Islamic organizations that were born in Indonesia have produced Islamic texts that are used for Islamic learning. One of them is the Muhammadiyah movement. I have reviewed a number of Islamic texts that I have written even though they were only introductory. You can see the review here: Siti Mariatul Kiptiyah, Warisan Islam Nusantara: Tafsir Al-Qur'an Carakan Dan Narasi Reformisme (Semarang: eLSA Press, 2020).

${ }^{3}$ This is one form of Muhammadiyah's appreciation of Javanese literacy, which has not been revealed by Burhani in his research on the closeness of the Muhammadiyah reformist movement with Javanese culture. To read Burhani's research: Ahmad Najib Burhani, Muhammadiyah Jawa (Yogyakarta: Suara Muhammadiyah, 2016).

${ }^{4}$ Kiptiyah, Warisan Islam Nusantara: Tafsir Al-Qur'an Carakan Dan Narasi Reformisme, 36-37.

${ }^{5}$ Fauzan Saleh, Modern Trends in Islamic Theological Discourse in 20th Century Indonesia (Leiden, Boston, Koln: Brill, 2001); Achmad Jainuri, Ideologi Kaum Reformis: Melacak Pandangan Keagamaan Muhammadiyah Periode Awal (Surabaya: LPAM, 2002); G.F. Pijper, Beberapa Studi TentangSejarah Islam Di Indonesia 1900-1950, ed. Tudjimah dan Yessy Augusdin, cet. ke-1 (Jakarta: UI Press, 1984); Thoha Hamim, "Moenawar Chalil's Reformist Thought: A Study of an Indonesian REligious Scholar (1908-1961)" (McGill University, 1996).
} 
teachings based on the Qur'an and hadith. The Qur'anic evidence and the traditions used as references are given contextual interpretations in solving the problems of society at that time.

Through the Swaraning Ngasepi manuscript, this paper will explore how Islam at that time was taught and studied. There are at least two crucial aspects to be explored, namely related to the historical situation that can be traced through the use of language and writing. The second aspect relates to the hermeneutical side or mindset that envelops the contents of the text, how the teachings of Islam are conveyed by the author through the Swaraning Ngasepi text.

It can enrich the study of Javanese Islamic manuscripts that have not touched many aspects of its composition which involve the Islamic movement as an author as well as a reader. some researchers who explore Indonesian manuscripts, they tend to pay more attention to Arabic-lettered manuscripts or pegons who were born in Pesantren environment. ${ }^{6}$ Indeed, the Pesantren is the oldest educational institution which is not only a place for teaching and learning but also for the production of a literacy culture and the birth of important Islamic works that can still be passed down through generations. This cannot be denied because the Pesantren literacy culture can still be witnessed until now in various similar institutions.

Based on this situation, the existence of the Swaraning Ngasepi manuscript must be read as an important work also at the time where it became a medium for the transformation of Islamic teachings. Of course, because the text carakan seems to give a different face to the teachings of Islam in boarding schools that tend to use Arabic and pegon (Arabic Javanese script). Another aspect that is also at the core of this study is the idea of the formation of Islamic culture in Javanese society which must always be based on the text of the Qur'an and Hadith.

This paper also offers another perspective on Muhammadiyah's studies. So far, there are not many studies on Muhammadiyah that put him in the position of an organization that has an important role in creating a Muslim community climate that is in line with the culture of the archipelago. This is probably due to the longstanding claim among scholars about Muhammadiyah as a reformist-modernist organization that reforms in various fields and is a very striking Islamic purification. Whereas in a several works of early Muhammadiyah

${ }^{6}$ Gusmian for example classifies the Qur'anic interpretation literature into three regions: Pesantren, Kauman, and Putihan. Characteristics of the Qur'anic interpretation on the basis of the Islamic Boarding School are Arabic or pegon inscriptions, in Kauman inscribed with means, and among Latin writers. Learn more, see Islah Gusmian, "Tafsir Al-Qur'an Bahasa Jawa: Peneguhan Identitas, Ideologi, Dan Politik Perlawanan," Suhuf 9, No. 1 (2016): 141-68. 
figures, ${ }^{7}$ it was seen how the contribution of the organization founded by Kiai Haji Ahmad Dahlan (m.1923) was in creating Javanese Muslim identity by Nusantara culture. For example, by respecting Javanese language and scripts through language retention in studying Islam $^{8}$ and other education. This is evidenced by the large number of Islamic literature written by Muhammadiyah scholars. Preservation of Javanese culture through the use of Javanese clothing in daily life and organizational meetings. ${ }^{9}$ Therefore, Burhani firmly said that since its establishment, Muhammadiyah was a representation of Javanese Islam. ${ }^{10}$

This study is documentary research, and the data are analyzed using philology. In the text of Swaraning Ngasepi, the function of philology is to understand the content of the text. Besides, it can look at the physical condition and the history of the manuscript.

\section{DISCUSSION}

The manuscript entitled Swaraning Ngasepi was compiled by two people named Sastra Atmaja, a Chairperson of Muhammadiyah Wonogiri, Central Java, and his scribe, R.M. Mh Sarjana. This manuscript contains lectures Kyai Muhtar Bukhari, a charismatic ulama who is also known as a tabligh teacher in Muhammadiyah Surakarta. Swaraning Ngasepi was published by Muhammadiyah Bagian Taman Pustaka in Wanagiri in 1938 with a thickness of 22 pages. Currently, one of Swaraning Ngasepi manuscripts is collected in the Library of Dewantara Kirti Griya Museum, Yogyakarta.

Although it appeared ten years after Sumpah Pemuda in which one of the points called for speaking Indonesian as the language of unity, Swaraning Ngasepi was written in carakan (hanacaraka) and Javanese language. It brings us to remember that nationalism does not necessarily erode local culture. The tradition of writing Javanese at that time still appreciated, even this modernist movement 26th-year-old. It can be imagined that the enthusiasm of Islamic symbols increased and has entered into the tradition of public literacy by presenting new readings about Islam. Even the reading emerged from the initiative to record lecture

\footnotetext{
${ }^{7}$ There are two views about the initial Muhammadiyah term. Burhani revealed the time span for the early Muhammadiyah between 1912-1930. The Jainuri gave an initial view on Muhammadiyah between 19121942. Read more: Jainuri, Ideologi Kaum Reformis: Melacak Pandangan Keagamaan Muhammadiyah Periode Awal.

${ }^{8}$ K.H. Ahmad Dahlan as the founder of Muhammadiyah allows his students to pray using Javanese. Sukriyanto AR, Kisah Inspiratif Para Pemimpin Muhammadiyah (Yogyakarta: Suara Muhammadiyah, 2017), 108-9.

${ }^{9}$ Burhani, Muhammadiyah Jawa, 96-97.

${ }^{10}$ Ahmad Najib Burhani, "The Ideological Shift of Muhammadiyah," Jurnal Masyarakat Dan Budaya 8, No. 1 (2006): 1-22.
} 
content. It shows a modern idea of reviving public literacy, such as a literacy program, considering that at that time there were many books of scholars could be used as a reference for studying Islam, and Swaraning Ngasepi completed it.

The activity of recording lecture content and then publishing it as a new book that can be accessed by the Javanese community, in general, gives a new style in Javanese Muslim literacy. Although this seems to adopt the style of the previous scholars like the Egyptian reformist lecture, Sheikh Muhammad Abduh written by his student, Sheikh Muhammad Rasyid Ridha and published in "Al-Manar" Magazine, also later the interpretation of AlManar which is very popular in Indonesia especially among modernists. There are similarities in the idea of compiling a teacher's lecture into a book that can be read by a wider audience. Ki Sastra Atmaja with his clerk in this context became "Rashid Rida" of Kiai Muhtar Bukhari Surakarta.

The term Swaraning Ngasepi can be interpreted as a subtle voice, whisper, wangsit, revelation, or inspiration. This title seems to present an important issue in the socio-religious life of the Javanese Muslims. It is not uncommon for some Javanese people to take a variety of ways to get a sense of what they want. This is closely related to the habits of Javanese people who do meditation, seclusion in quiet places to gain knowledge through wangsit. This custom is already present in the stories of ancestors in the chronicles, including the Javanese chronicle.

\section{Swaraning Ngasepi and Islamic Brotherhood of Javanese Muslim}

The first discussion in the Swaraning Ngasepi is Hayuning Bawana which means the beauty of the world. Javanese people have a philosophy of living memayu hayuning bawana which has relevance to Javanese cosmology. Bawana or the world is the universe or the place of human life in reality. Therefore, if humans live in the universe together to plant a lot of goodness, then one day they will reap the benefits of goodness. Related to this issue, the author outlines the topic of Hayuning Bawana in the first place with a call to cultivate the ties of brotherhood among fellow humans, as the following quote:

"Panjênêngan tamtu sampun mangêrtos bilih sadaya tiyang Ngeslam punika sadherek. Sanadjan ingkang manggen ing sanes nagari, lan sanadjan botên tunggil bongsa. Makatên punika mawi tangsul inggih punika: Agami Ngeslam. Langkung-langkung ingkang tunggil padunungan. Kados kula sadaya tiyang Jawi ingkang siti wutahrahipun ing tanah Jawi. Botên kêdah saya rumakêt pasadherekanipun awit kajawinipun tangsuli dening agami inggih tunggil 
bongsa, tunggil kabêtahan. Awit saking punika murih sagêd kadumugen ing sêdya kita, kita kêdah nambahi ing karukunan kita lan purun ngrêmbag punapa ingkang dados kabêtahanipun jalaran manawi tansah cêcongkrahan têmtu botên badhe sagêd kadumugen ing sêdya kita sadaya."11

"You should know that all Muslims are brothers. Even though they live in different countries and even though they are not from the same nation. Such is the mutual attachment of Islam. The more so fellow regional, like me, all Javanese whose homeland is in the land of Java. Not only is his brotherhood becoming tighter because his Javanese is tied to religion, the nation, and the same needs. Therefore, to achieve the same goal, we need to increase our harmony and be willing to deliberate on what is needed because there may be feuds of course we will not be able to achieve our common goals."

In the first sentence, it recounts a hadith about brotherhood among fellow Muslims. In Sahih Bukhari number 2262 it was mentioned a hadith that said that a Muslim is a brother of another Muslim. Therefore, it is not allowed to wrong each other and underestimate or hurt. ${ }^{12}$

In further information, the author also adds another hadith which is also still contained in Sahih Bukhari number 5605 to strengthen his statement. In the last hadith mentioned above, there is a prohibition not to hate one another, envy and hostile to each other, as well as an order to establish brotherhood among fellow servants of Allah, and a prohibition on cutting off relations or hostile to Muslim brothers for more than three days. ${ }^{13}$

In addition to the two traditions above, the author of Swaraning Ngasepi also quoted QS. Al-Hujurat: 10 as a reinforcing proposition on how to maintain the fraternity is highly recommended in Islam.

Based on the arguments presented, the author adds that maintaining brotherhood is a physical movement that must be sought. For example, by organizing the larger the organization, the stronger the sense of kinship. If only by staying silent, the brotherhood will end up breaking. ${ }^{14}$ The Javanese say that in terms of pati obor.

There are two forms of brotherhood described by the author in the Swaraning Ngasepi text, namely brotherhood because of the world and brotherhood because of Allah Ta'ala. According to the author of Swaraning Ngasepi, the first is the most dangerous form.

\footnotetext{
${ }^{11}$ Sastra Atmaja, Swaraning Ngasepi (Wanagiri: Muhammadiyah Bagian Taman Pustaka, 1938), 5.

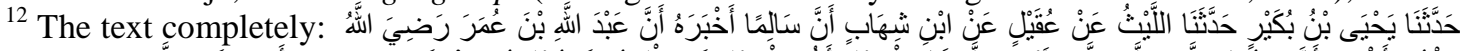

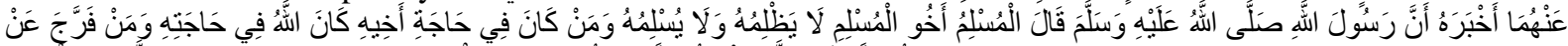

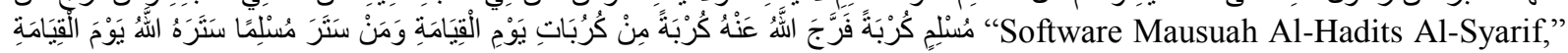
n.d.

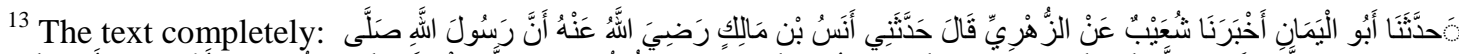

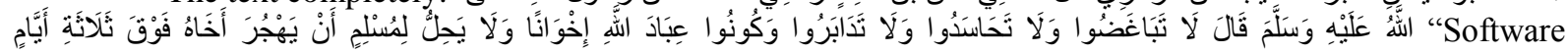
Mausuah Al-Hadits Al-Syarif."

${ }^{14}$ Atmaja, Swaraning Ngasepi, 5.
} 
Brotherhood because the world will only be realistic to see others. A feature of brotherhood because the world is if someone is rich, has a lot of property, be handsome, has a high position, will be approached, and made a close friend. Conversely, if the person becomes poor, sick, physically disabled, or does not have a job will be left. The brotherhood because of Allah, will look at other people alike under any circumstances and remind each other to always be on the path to seek the pleasure of Allah. Efforts to remind each other can be through isyarah (by expressing something), kinayah (majaz), and sarihah (clear) ${ }^{15}$. Therefore, those are recommended for every Muslim to apply.

\section{Mistical guidance from Reading the Qur'an}

The second topic discussed by the author is about trilaksiteng wangsit. In this regard, Swaraning Ngasepi describes that God gives guidance to humans through His books carried by the messengers, the Prophets and Apostles, and through His nature. The second form is what the author referred to as the Swaraning Ngasepi. Directions through nature are also contained in the book of the Qur'an as mentioned by QS. Shad: 29. For this reason, according to the author, those who want to get clear whispers must multiply read and study the Qur'an. ${ }^{16}$

The Swaraning Ngasepi statement above clearly refers to efforts to create the Islamic culture to the Javanese community. One of which is to get inspiration it must return or refer to the Qur'an as a source of Islamic teachings. The term "back to the Qur'an and Hadith", in the context of Indonesia has become a slogan among reformers, including Muhammadiyah. The slogan emerged as the impact of modernism and global reformism in the Islamic world. As a consequence, the reformers exalt the spirit of returning to the Qur'an and the Hadith. Muhammadiyah itself has repeatedly called for the slogan together with an invitation to the spirit of ijtihad and against the attitude of imitation (taqlid). ${ }^{17}$

According to Peacock, as a puritan movement, Muhammadiyah invites Muslims to return to the Qur'an and Hadith to purify the faith of khurafat and formalism. ${ }^{18}$ Purification in practice is considered important to eradicate all mystical elements, animism, dynamism,

\footnotetext{
15 Atmaja, 7-13.

${ }^{16}$ Atmaja, 14-15

${ }^{17}$ Saleh, Modern Trends in Islamic Theological Discourse in 20th Century Indonesia, 85.

${ }^{18}$ James L. Peacock, Gerakan Muhammadiyah Memurnikan Ajaran Islam Di Indonesia (Yogyakarta: Suara Muhammadiyah, 2016), 29
} 
Hinduism, and Buddhism which are members of syncretic Islam. Through this purification, the reformers sought to rediscover true Islam. ${ }^{19}$

In the Swaraning Ngasepi, returning to the Qur'an and Hadith becomes important in finding good whispers or inspiration. This is because that subtle whisper can arise from many things. If it arises from an angel, then the contents of the whisper can be sure to have relevance or compatibility with religious law. This is what is called an inspiration. Unlike the case with al-hawajis or whispers that come from the lust that often invites actions that lead to immorality. The third and most severe type is anxiety or whispering from satan that guides a person to commit immoral acts. The most correct whispers are those that come from Allah Ta'ala directly to the servants that He loves. It is this latter whisper that is highlighted by the author of Swaraning Ngasepi and becomes an idea of what someone who wants to get a revelation must strive for.

"Kathah kemawon tiyang ingkang ngudi badhe mirêngakên swaraning ngasêpi, nanging nyingkur dhatêng Qur'an têmtu adhakan kêsasaripun jalaran upami tiyang mlampah makatên lumampah ing pêtêngan ingkang botên ambêkta obor. Dados nyanuk nyanuk utawi gagap-gagap. Ananging sanadjan mawi obor bilih pambêktanipun wontên ing wingking inggih tangeh sagêd dipun enggal dumugi. Awit gundhukan badanipun piyambak beda kaliyan manawi obor kadekek wonten ing ngajêng." 20

"Many people who insist on listening to subtle whispers, but turning away from the Qur'an must be lost because it is like people walking in darkness without light. Thus, he limped. But despite carrying the torch, the torch was behind him so it was still unable to reach the destination immediately because of the shadow of his own body, in contrast to if the torch was in front of him."

Based on the information above, according to the author, unfortunately, many people who seek wangsit without being guided by the Qur'an so that it does not give birth to good deeds and increase religiosity, but instead get lost from religious teachings. This is where the importance of understanding Islam from its main sources namely the Qur'an and Hadith.

\section{CONCLUSION}

The Islamic culture initiated by the author in the Swaraning Ngasepi manuscript is related to fostering brotherhood and obtaining authority from Allah Ta'ala. In the context of Javanese society, the term srawung is known which means social. This is then conveyed again

\footnotetext{
${ }^{19}$ James L. Peacock, Gerakan Muhammadiyah Memurnikan Ajaran Islam Di Indonesia (Yogyakarta: Suara Muhammadiyah, 2016), 29

${ }^{20}$ Atmaja, Swaraning Ngasepi, 15.
} 
by the author with the affirmative arguments taken from the Qur'an and the hadith regarding the importance of maintaining ukhuwah among fellow humans. One way to care for brotherhood is to organize. Thus, this shows that the author's idea of what is called hayuning bawana through caring for the silaturrahim rope clearly illustrates the identity of modern Javanese Muslims.

Furthermore, related to the interpretation of Swaraning Ngasepi or subtle whispers, the author invites the Javanese Muslim community to seek inspiration with the right path, namely through Islamic teachings, back to the Qur'an and Hadith. This is part of the effort to make Islam in the middle of Javanese society which at that time was accustomed to doing asceticism, seclusion in caves, mountains, riverbanks, and so on to obtain visions. Kiai Muhtar Bukhari's advice which was compiled by Kiai Sastra Atmaja is certainly an attempt to break the tradition that is not by Islamic teachings.

The idea about the making of Islamic culture in the Swaraning Ngasepi is to obtain revelation through Islamic procedures and criticizes the practice of asceticism in solitude in the lonely places that the Javanese people used to do in the past to obtain magical guidance. In other words, through the Swaraning Ngasepi text there is the author's attempt to create the Islamic culture to the Javanese Muslim, which is Islamic in the sense that every deed is based on the Qur'an and Hadith.

\section{BIBLIOGRAPHY}

AR, S. (2017). Kisah Inspiratif Para Pemimpin Muhammadiyah Cet. ke-1. Yogyakarta: Suara Muhammadiyah.

Atmaja, S. (1938). Swaraning Ngasepi. Wanagiri: Muhammadiyah Bagian Taman Pustaka.

Burhani, A. N. (2006). The Ideological Shift of Muhammadiyah. Jurnal Masyarakat Dan Budaya 8 No 1, 1-22.

Burhani, A. N. (2016). Swaraning Ngasepi. Yogyakarta: Suara Muhammadiyah.

Gusmian, I. (2016). Tafsir Al-Qur'an Bahasa Jawa: Peneguhan Identitas, Ideologi, Dan Politik Perlawanan. Suhuf 9, no. 1, 141-168.

Hamim, T. (1996). Moenawar Chalil's Reformist Thought: A Study of an Indonesian REligious Scholar (1908-1961). McGill University.

Jainuri, A. (2002). Ideologi Kaum Reformis: Melacak Pandangan Keagamaan Muhammadiyah Periode Awal. Surabaya: LPAM. 
Kiptiyah, S. M. (2020). Warisan Islam Nusantara: Tafsir Al-Qur'an Carakan Dan Narasi Reformisme. Semarang: eLSA.

Peacock, J. L. (2016). Gerakan Muhammadiyah Memurnikan Ajaran Islam Di Indonesia. Yogyakarta: Suara Muhammadiyah.

Pijper, G. (1984). Beberapa Studi TentangSejarah Islam Di Indonesia 1900-1950. Edited by Tudjimah dan Yessy Augusdin. Cet. ke-1. Jakarta: UI Press.

Saleh, F. (2001). Modern Trends in Islamic Theological Discourse in 20th Century Indonesia. Leiden, Boston, Koln: Brill.

Software Mausuah Al-Hadits Al-Syarif. (n.d).

Umam, Z. K. (2017). Islam, Arsip, Dan Arsipelago: Sebuah Refleksi Keindonesiaan. Jurnal Sejarah, l(1), 105-120. 